\title{
Review
}

\section{Public Things: Democracy in Disrepair}

\author{
Bonnie Honig \\ Fordham University Press, New York, 2017, xiii+144pp., \\ ISBN: 978-0-8232-7641-7
}

Contemporary Political Theory (2018) 17, S205-S208. https://doi.org/10.1057/s41296017-0149-4; published online 19 September 2017

Corn, sewages, public phones, and tables - these objects are just a few of the things that Bonnie Honig enlists for revitalizing democratic politics in her new book Public Things: Democracy in Disrepair. Against the backdrop of the ongoing privatization of public services and spaces in current neoliberal societies, Honig presents an invigorating and subtle argument that public things 'interpellate us into democratic citizenship' (p. 5).

Public Things is based on three (substantially revised) public lectures that Honig delivered in Australia and that were broadcast on the radio there. In addition to the lectures, the book includes a preface, an introduction, and an epilogue, where Honig compares her theory of public things with other recent theories about the spatial dimension of collective action, such as the commons.

Honig engages neoliberalism most directly in lecture one where she makes a case for public things in dialogue with Wendy Brown's recent critique of neoliberalism. In Undoing the Demos (2015) Brown argues that the neoliberal focus on market rationality has displaced distinct democratic aspirations, such as the orientation towards the common good and the desire for popular sovereignty. Honig agrees with Brown that neoliberalism hollows out democratic politics, but, more optimistically than Brown, sees possibilities for meaningful collective resistance against neoliberalism. The aspiration for sovereignty has not been 'lost,' but 'dispersed and relocated' (p. 27). For example, Honig calls attention to local movements that press for food sovereignty, such as the indigenous Mayan people in Guatemala. This movement organized mass protests against attempts by the multinational corporation Monsanto to patent their corn seeds and successfully reclaimed the freedom to own and cultivate their own seeds. What Honig retrieves from this example and many others is that collective democratic action constitutively depends upon public things, that is, objects that are collectively owned or available for public use. Unlike privately owned things, such as an iPhone, public things nourish a desire to 'share the experience of being part of something that is larger than ourselves, and work with others, acting in concert, to

(C) 2017 Macmillan Publishers Ltd. 1470-8914 Contemporary Political Theory Vol. 17, S4, S205-S208 
share it, to democratize access to it ... to maintain it' (p. 36). On the one hand, Honig insists on the value of public things for criticizing the undemocratic effects of neoliberal privatization: without public things 'action in concert is undone and the signs and symbols of democratic life devitalized' (p. 4). Yet, her argument also offers a fresh angle on the challenge of transforming critiques of neoliberalism into collective struggles: Honig shows that public things 'still enchant' and can orient resistance against the current political economy.

If there is anything wanting in Honig's analysis of neoliberalism it might be a more sustained reflection on how markets too have discovered and cultivated our longings for public things. For example, the desire to contribute to a more sustainable food economy or to support local farming not only animates the resistance movements mentioned by Honig (such as slow food and food sovereignty), but has also been co-opted by multinational corporations for whom organic food has become 'a wildly lucrative business' (Strom, 2012). To be sure, Honig is aware that neoliberalism actively blurs the boundaries between the private and public and does mention that the 'desire for a democracy of public things has been in recent decades rechannelled into commercial formats' (p. 31). But the overarching message of her critique is that neoliberalism does not take seriously the desire for public things. For example, she argues that neoliberalism focuses too much on efficiency and wrongly treats the longing for public things - such as social welfare programs - as immature. Since markets are so successful in capitalizing on our public ambitions, Honig might have paid more attention to the way in which citizens in neoliberal economies satisfy their desire for public things through the consumption of public/private goods - and the effect this has upon democratic citizenship.

For readers familiar with Honig's earlier work, it does not come as a surprise that she aims for an agonistic theory of public things. Rather than a nationalist or communitarian account where people stand united in their love for particular public objects (flags, statues, land), Honig considers 'contestation,' even 'antipathy' (p. 4) of public things, no less than common love, as healthy democratic relationships to objects. Furthermore, following thing theorists, such as Bruno Latour and Jane Bennett, Honig attributes agency to things and emphasizes that things not only express human desires or intentions, they also have the power to disrupt, provoke, and instruct us. In lecture two, Honig develops her own political theory of things through an original and intriguing engagement with Hannah Arendt and the psychoanalyst Donald Winnicott - two thinkers who, to my knowledge, have not yet been brought together in support of a thing theory. Focusing on the 'Work' section of The Human Condition, Honig illuminates the way that Arendt considers the fabrication of things, such as memorials, sculptures and poems, essential for establishing and sustaining human relations over time. Such things provide the stable 'infrastructure' for the vicissitudes of action: the political domain, structured by contingency, where human beings realize their capacity to 'care for the world' 
through action in concert. Without losing sight of their differences, Honig develops a striking parallel between the Arendtian care for the world and what Winnicott calls the 'capacity for concern': the ability of humans to be concerned with a world that is 'not-me,' rather than being led entirely by the impulse to satisfy immediate needs. In Winnicott's account, children - and adults too - realize this capacity through their attachment to 'transitional' objects: things that charm us, but also provoke and annoy us when they frustrate our wishes. When things survive our fantasies of destruction, they teach us that the world has a certain permanence that is indifferent to our fantasy life, thus enabling the development of a desire to contribute to the world. The key insight, then, that Honig derives from Arendt and Winnicott is that human beings' capacity to contribute to the world and to objects are mutually constitutive: 'we make things and things condition our existence' (p. 46). Neoliberalism undermines the circular relation between human beings and public things: like the raging omnipotent child, it sets out to 'destroy public things,' but offers no stable public infrastructure that 'may yield to the test' (p. 56).

Honig pursues the relevance of (creating) object permanence in lecture three by way of two rich readings of Jonathan Lear's book Radical Hope and Lars Von Trier's film Melancholia. As in lecture one, the focus is on how people might respond when public things are in jeopardy, but here Honig adds a new term to her vocabulary of thing theory, hope, and she argues that making public things is key to establishing hope in dire circumstances. For example, in Von Trier's film the main characters play with wood to make a shelter - fantasized as a 'magic cave' - in response to earth's imminent collision with planet Melancholia. Rather than dismissing the cave for being inefficient - it is too fragile to offer adequate protection - Honig highlights how the collaborative practice of making the cave establishes an empowering collective and how, in turn, the stable and shared presence of the cave gives its builders hope in the face of catastrophe.

Overall, Honig carefully lays out how things and collective action are mutually dependent upon one another. In comparison, her theoretical account of thing agency feels a bit sketchy. She persuasively employs Winnicott's theory about object permanence to show that engagement with things can make people mindful about the existence of a material world that exceeds the self (p. 55). But how do people become aware of and responsive to the specific agentic characteristics of the objects that constitute this world? Honig's discussion of the Mayan struggle for food sovereignty notes that people can take 'instruction' from the 'agency' of objects. For instance, Honig cites Lolita Chavez from the Mayan People's Council who says that the cultivation of corn taught this community how much corn and other crops are interdependent and that corn thus showed the group 'how to relate with the surrounding world' (p. 21). This is a powerful example, but theoretically Honig does not really clarify how people develop such a sensitive orientation towards the material particularities of things. It would have been useful if Honig had engaged more in depth with the work of other thing theorists, such as Jane

(C) 2017 Macmillan Publishers Ltd. 1470-8914 Contemporary Political Theory Vol. 17, S4, S205-S208 S207 
Bennett (2009), who emphasizes the need to develop a 'cultivated, patient, sensory attentiveness' to non-human forces. More generally, the question arises how Honig positions her own political theory of things vis-à-vis other recent thing theories. She says that while her work is 'indebted' to thing theory, it is also different, as 'the human remains the focus' (p. 28). Is this an implicit critique of thing theory? Or does she consider her approach complementary to posthumanist approaches? In this respect, too, more engagement with recent literature would have been welcome.

Nevertheless, Honig's book amply realizes what I take to be its most important mission: illuminating the need for public things in democratic life when the political economy deprives us of such things. Honig's arguments and lively prose are compelling and make a convincing plea to shift the gaze away from the iPhone towards the fragile public infrastructure - parks, subways, bridges - around us.

\section{References}

Bennett, J. (2009). Vibrant Matter: A Political Ecology of Things. Durham: Duke University Press. Brown, W. (2015). Undoing the Demos: Neoliberalism's Stealth Revolution. New York: Zone Books. Strom, S. (2012). Has 'organic' been oversized? New York Times, July 8. Retrieved from http://www. nytimes.com/2012/07/08/business/organic-food-purists-worry-about-bigcompanies-influence.html. Accessed 18 Sept 2017.

Irena Rosenthal University of Amsterdam, 1012 WX Amsterdam, The Netherlands i.rosenthal@uva.nl 